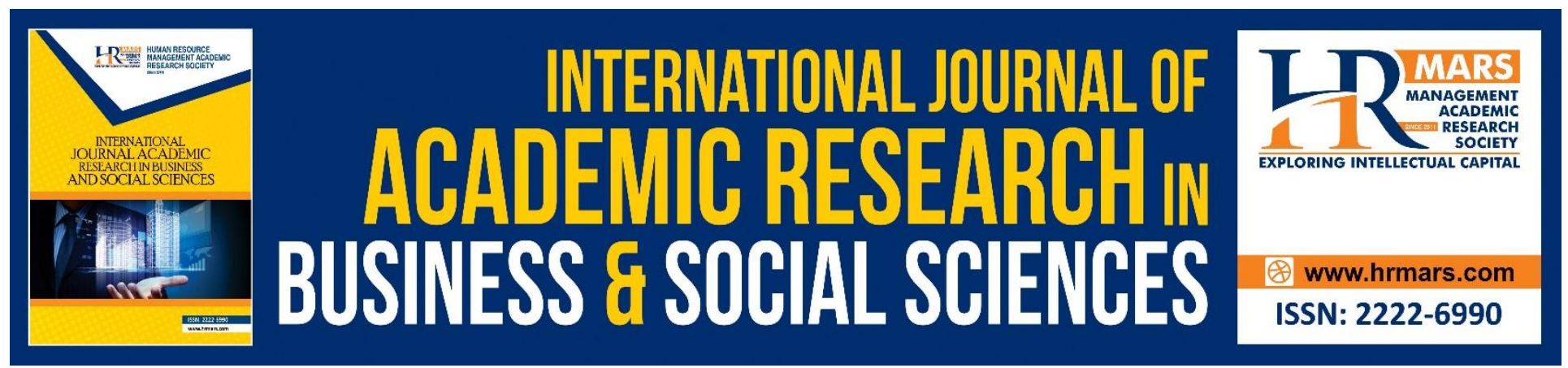

\title{
Dietary Supplement Intake: A Study on its Associated Factors among University Students in Terengganu
}

Nurul Fathin Mohd Yazid, Fatimah Syahirah Azli, Fatimah Abd Ghani,
Noorazlin Ramli, Norhayati Mohd Yusof

To Link this Article: http://dx.doi.org/10.6007/IJARBSS/v11-i13/8500 DOI:10.6007/IJARBSS/v11-i13/8500

Received: 09 November 2020, Revised: 10 December 2020, Accepted: 30 December 2020

Published Online: 22 January 2021

In-Text Citation: (Yazid et al., 2021)

To Cite this Article: Yazid, N. F. M., Azli, F. S., Ghani, F. A., Ramli, N., \& Yusof, N. M. (2021). Dietary Supplement Intake: A Study on its Associated Factors among University Students in Terengganu. International Journal of Academic Research in Business and Social Sciences, 11(13), 33-42.

Copyright: (C) 2021 The Author(s)

Published by Human Resource Management Academic Research Society (www.hrmars.com)

This article is published under the Creative Commons Attribution (CC BY 4.0) license. Anyone may reproduce, distribute, translate and create derivative works of this article (for both commercial and non-commercial purposes), subject to full attribution to the original publication and authors. The full terms of this license may be seen

at: http://creativecommons.org/licences/by/4.0/legalcode

Special Issue: Beyond 2021 and COVID-19 - New Perspective in the Hospitality \& Tourism Industry, 2021, Pg. 33 - 42 http://hrmars.com/index.php/pages/detail/IJARBSS JOURNAL HOMEPAGE

Full Terms \& Conditions of access and use can be found at http://hrmars.com/index.php/pages/detail/publication-ethics 


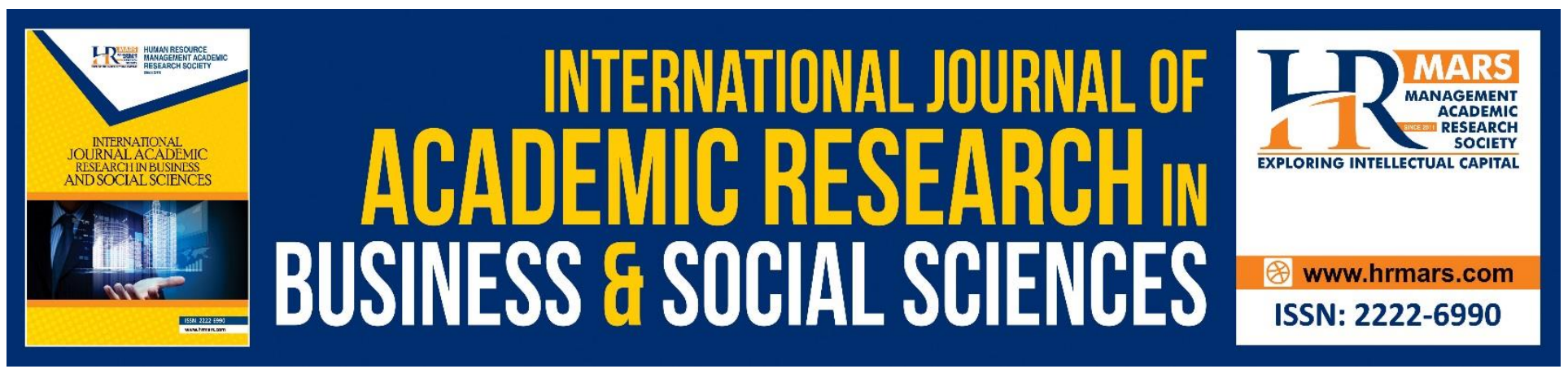

\title{
Dietary Supplement Intake: A Study on its Associated Factors among University Students in Terengganu
}

\author{
Nurul Fathin Mohd Yazid ${ }^{1}$, Fatimah Syahirah Azli ${ }^{1}$, Fatimah Abd \\ Ghani ${ }^{1}$, Noorazlin Ramli ${ }^{1}$, Norhayati Mohd Yusof ${ }^{2}$ \\ ${ }^{1}$ Faculty of Hotel \& Tourism Management, Universiti Teknologi MARA, Dungun, \\ Terengganu, Malaysia, ${ }^{2}$ Faculty of Hotel \& Tourism Management, Universiti Teknologi MARA, \\ Puncak Alam, Selangor, Malaysia
}

\section{Abstract}

The aim of this paper is to determine the associated factors that influence students' decision to have a dietary supplement in their daily intake. The participants for this study are bachelor degree students in three Terengganu local universities. Data were obtained through online questionnaires. Among 406 respondents, 126 (30.9\%) are currently using dietary supplements. The prevalence of dietary supplement used does not differ significantly between males and females. However, most respondents claimed decreases in their Body Mass Index - and it is higher in non-associated science students as compared to science-associated students. The most used sources of information are the internet, and the most popular places to obtain their supplement are pharmacy and drugstore. Furthermore, the main reason for dietary supplement consumption is to maintain their health level, and most of them consumed only one supplement. Results of this study extend and provide additional information to the existing research by extending the area of research and beneficial to the supplement industry, especially in Terengganu. However, future research in this area is recommended to expand in other area and population in Malaysia. Therefore, supplement consumption among university students is still controllable.

Keywords: Supplement Prevalence, Supplement Intake, Dietary Supplement, Adverse Effect.

\section{Introduction}

People have been widely exposed to the importance of supplement through the media presence. Many people, especially young adults with hectic schedules, will substitute the missing nutrient in their diet with the dietary supplement. Based on the current research, supplement intake may occasionally be uncontrolled without any supervisory and may affect the consumers' health. Besides, there are ample shreds of evidence on the fact that dietary supplements have been used without any consultation from the medical professionals and people are unaware of the side effects. With that, the utmost factor that triggers this study to be conducted is that the researcher intends to 
investigate the relationship between dietary supplement intake among students and its associated factors. Besides, the consumption of supplement has become uncontrollable, and people consume it without any further justification or serious reasons (Barnes et al., 2016). The consumption of the dietary supplement is also increasing in developing countries, whereby $75 \%$ of individuals consume more than one type of supplement at one time (Bessada et al., 2018).

This research aims to determine the associated factors that influence students' decision to have the dietary supplement in their daily intake and investigate the relationships between three associated factors that are external factors, internal factors, and the supplement intake adverse effect on students' prevalence of dietary supplement consumption. External factors include the source of information and a place to obtain a dietary supplement. Purpose of supplement consumption, type of supplement consumed, and student's level of awareness on the dietary supplement is categorised under internal factors that will affect the prevalence of dietary supplement consumption. As for the adverse effect, it focuses on the experience of the adverse effect itself and their response towards it. Each of the factor chosen is based on the findings from several studies made by several researchers who agreed that it would affect the prevalence of dietary supplement (Alfawaz et al., 2017; Chiba et al., 2017; Kobayashi et al., 2017; Fattahzadeh-ardalani et al., 2016; Al-Naggar \& Chen, 2011).

\section{Literature Review}

\section{Dietary Supplement and Its User}

Akabas et al. (2016) defined dietary supplement as products that are consumed to complete or enhance the diet without containing any tobacco. It is also consumed to help prevent diseases, maintain health, or provide extra energy to the body (Barnes et al., 2016; Fattahzadeh-ardalani et al., 2016). The number of people that consumed dietary supplement is more than half of the population in the United States, and this has been approved by several researchers (Blumberg et al., 2017; Akabas et al., 2016; Knapik et al., 2016; Barnes et al., 2016). In addition, the number of people consuming supplement in the United States keeps increasing with its percentage becoming closer to $100 \%$ (Blumberg et al., 2017). In Malaysia, Zaki et al. (2018) concluded that the prevalence of Vitamins/Mineral Supplements (VMS) and Food Supplements (FS) intakes among adults were 28.1\% and $34.0 \%$ respectively. Older aged adult women with higher education level and monthly income are more probable to consume dietary supplements. Vitamin C and multivitamin/ multi-mineral are the commonest VMS consumed by the respondents. The most common FS taken are fish oil and royal jelly. The main reasons for dietary supplements intake include for health reasons, doctor's prescription, to increase energy level, and for beauty. About one-third of the Malaysian adults consumed a variety of dietary supplements. Thus, information based on the scientific shreds of evidence of health benefits for each type of dietary supplements is needed to facilitate consumers to make informed choices on the dietary supplements.

\section{External Factors: Source of Dietary Supplement and Place to Obtain Dietary Supplement}

Most of the consumers obtain the information of supplements through the internet (Žeželj et al., 2018), which is also supported by other researchers stating that internet has the biggest influence on consumers (Jawadi et al., 2017; Barrack \& Gray, 2017). Family is also one of the biggest information sources with a percentage of 41.3 percent $(41.3 \%)$ on supplement intake (Axon, Vanova, Edel, \& Slack, 
2017; Circella, 2017). Besides, friends holding a percentage of 20.5 percent $(20.5 \%)$ or any close acquaintances based on a study done in Malaysia (Yeong \& Choong, 2017). As for the place to obtain dietary supplement, drugstore is the most chosen place to buy a supplement in Japan by a significant percentage of 63.7 percent (63.7\%) (Chiba et al., 2017). Some of the consumers also obtain it through internet (19.6\%) (Kobayashi et al., 2017).

\section{Internal Factors: Purpose of Dietary Supplement, Type of Supplement Used, and Level of Awareness}

Most of the consumers used dietary supplement as one of the methods to reduce their weight (Fattahzadeh-ardalani et al., 2016). Another recent study made in Saudi Arabia proved that people consume the supplement to improve their appearances (Naqvi, Ahmad, Abdul, Elewi, \& Alawa, 2018). According to Knapik (2016), multivitamin or multi-mineral supplement is the type of supplement that contains two or more vitamins or minerals without any presence of other substances. Protein supplement is a supplement that intends to provide extra protein to its user, while the herbal supplement is classified as a supplement with one or more herbal ingredients in its content (Knapik et al., 2016). The percentage of people that are actually aware of the importance of consuming a supplement with professional prescription is at 70 percent $(70 \%)$, and the rest are unsure on the difference of with or without prescription (Alfawaz et al., 2017). The high level of awareness on the importance of dietary supplement increases the prevalence of dietary supplement intake (Kobayashi et al., 2017).

\section{Adverse Effect: Experience and Response}

Some supplement users may or may not experience the adverse effect of supplement intake. The usage of dietary supplement may result in several effects when the consumption achieves to some extent, and the effect may be hypertension, antibiotic-associated diarrhea, ill, and more (Marx et al., 2016). In Japan, most of the consumers tend to do nothing when they are experiencing an adverse effect of supplement intake (Kobayashi et al., 2017).

\section{Prevalence of Dietary Supplement Intake}

Prevalence of dietary supplement study has been done in several countries and settings (Kobayashi et al., 2017; Alfawaz et al., 2017; O'Brien et al., 2017). Most of the studies relate the strength of each determinant towards the probability of student in consuming supplements. Kobayashi et al. (2017) conducted a study on the prevalence of dietary supplement used among college students, while Alfawaz et al. (2017) made a study on the prevalence of dietary supplement used and the associated factors among female college students in Saudi Arabia. Both studies have recommended that more researchers should conduct studies on dietary supplement intake to help increase awareness and basic knowledge related to supplements. Therefore, this study is made to fill in the gap as there is no study yet found on the prevalence of dietary supplement intake and its associated factors.

\section{Methodology}

This study unit of analysis are bachelor's degree students from Universiti Teknologi MARA (UiTM), Universiti Terengganu Malaysia (UMT), and Universiti Sultan Zainal Abidin (UniSZa) in 
Terengganu. The number of respondents required is determined by Krejcie and Morgan (1970) sampling table. Based on the table by Krejcie and Morgan, 379 students $(n=379)$ are considered sufficient to represent the whole population for this study. The questionnaire for this study is prepared and distributed by an online questionnaire, and data are collected by the researcher through Google Form. Pilot test as a way in pre-testing the questionnaire is conducted before the online questionnaire is distributed out to respondents. Each of the factor of dietary supplement consumption has been analysed by using SPSS software version 24.0 to test its reliability. Cross tabulation table is used in order to summarise the obtaining value. Multiple answers. Statistical analyses were conducted between males and females. $\mathrm{p}$-values were calculated using $\times 2$ test.

\section{Result and Analysis}

The information on the sources of information about dietary supplement used by the respondents is shown in Table 1 below.

Table 1: Source of Information on Dietary Supplements (\%)

\begin{tabular}{lllll}
\hline & All & Male & Female & $\boldsymbol{p}$-Value \\
\hline Television & 15.3 & 17.4 & 14.9 & 0.605 \\
\hline Radio & 4.5 & 2.9 & 4.8 & 0.491 \\
\hline Newspaper, magazines, flyers & 13.9 & 11.6 & 14.3 & 0.549 \\
\hline Internet & 37.9 & 36.2 & 38.2 & 0.758 \\
\hline Medical assistance & 17.4 & 11.6 & 18.6 & 0.164 \\
\hline Family & 9.9 & 2.9 & 33.2 & 0.032 \\
\hline Friends or acquaintances & 9.7 & 10.1 & 9.6 & 0.885 \\
\hline
\end{tabular}

The most commonly used sources of information among respondents are the internet (37.9\%). This is followed by medical assistance (17.4\%), the television (15.3\%), newspapers, magazines and flyers (13.9\%), family members (9.9\%), friends or acquaintances (9.7\%), and lastly from the radio (4.5\%). Females majorly find information regarding dietary supplement from their family as compared to males with a p-value of 0.032 . 
INTERNATIONAL JOURNAL OF ACADEMIC RESEARCH IN BUSINESS AND SOCIAL SCIENCES

Vol. 11, No. 13, Beyond 2021 and COVID-19 - New Perspective in the Hospitality \& Tourism Industry. 2021, E-ISSN: 2222-6990 @ 2021 HRMARS

External Factor: Place to Obtain Supplement

The information on the place to obtain dietary supplement by the respondents is shown in Table 2 below.

Table 2: Place to Obtain supplement (\%)

\begin{tabular}{lllll}
\hline & All & Male & Female & $\boldsymbol{p}$-Value \\
\hline Pharmacy, drugstore & 40.2 & 36.2 & 41.0 & 0.460 \\
\hline Retail store, supermarket & 10.5 & 1.4 & 12.3 & 0.007 \\
\hline Online shop & 12.5 & 14.5 & 12.0 & 0.576 \\
\hline Family & 10.1 & 10.1 & 10.1 & 0.999 \\
\hline Friends or acquaintances & 5.9 & 8.7 & 5.4 & 0.288 \\
\hline
\end{tabular}

Analysis of data shows that the most popular place chosen by the respondents in obtaining their supplement is pharmacy and drugstore (40.2\%). This is followed by online shops (12.5\%), retail store and supermarket (10.5\%), family (10.1\%), and then friends or acquaintances (5.9\%). There are some gender differences found in respondents who obtaining supplement from retail store or supermarket. It is found that women (12.3\%) tend to buy their supplement in retail store as compared to men (1.4\%) with a p-value of 0.007.

\section{Internal Factor: Purpose of Dietary Supplement Consumption}

The purpose of dietary supplement consumption by the respondents are reported in Table 3 below.

Table 3: Purpose of dietary supplement consumption (\%)

\begin{tabular}{lllll}
\hline & All & Male & Female & $\boldsymbol{p}$-Value \\
\hline Maintenance of health & 44.1 & 34.8 & 46.0 & 0.088 \\
\hline Beauty benefits & 21.8 & 10.1 & 24.3 & 0.010 \\
\hline Weight loss & 12.1 & 15.9 & 11.3 & 0.287 \\
\hline Weight gain & 5.2 & 5.8 & 5.1 & 0.806 \\
\hline Building muscle & 2.0 & 4.3 & 1.5 & 0.121 \\
\hline Treatment of disease & 10.4 & 4.3 & 11.6 & 0.071 \\
\hline
\end{tabular}

Results show that the main objective of dietary supplement consumption is for maintaining their health level (44.1\%). The other reasons are for beauty benefits (21.8\%), weight losing (12.1\%), disease treatment (10.4\%), weight gaining (5.2\%), and muscle building (2\%). There has been a major difference between genders in the purpose of consuming dietary supplement for beauty benefits as female $(24.3 \%)$ are prone to it as compared to male (10.1\%) with p-value 0.010 . 
INTERNATIONAL JOURNAL OF ACADEMIC RESEARCH IN BUSINESS AND SOCIAL SCIENCES

Vol. 11, No. 13, Beyond 2021 and COVID-19 - New Perspective in the Hospitality \& Tourism Industry. 2021, E-ISSN: 2222-6990 @ 2021 HRMARS

\section{Internal Factor: Type of Supplement Used}

The type of dietary supplement used by the respondents are reported in Table 4 below.

Table 4: Type of Supplement Used (\%)

\begin{tabular}{lllll}
\hline & All & Male & Female & $\boldsymbol{p}$-Value \\
\hline Mineral supplements & 10.9 & 13.0 & 10.5 & 0.534 \\
\hline Vitamin supplements & 37.2 & 31.9 & 38.3 & 0.314 \\
\hline Herbal supplements & 3.7 & 10.1 & 2.4 & 0.002 \\
\hline Protein supplements & 1.7 & 0 & 2.1 & 0.226 \\
\hline Fish oil supplements & 3.0 & 0 & 3.6 & 0.110 \\
\hline Sunnah supplements & 2.2 & 0 & 2.7 & 0.169 \\
\hline
\end{tabular}

The most popular type of dietary supplement consumed by respondents is vitamin supplements (37.2\%). Other types of supplement consumed by respondents are mineral supplements (10.9\%), herbal supplements (3.7\%), fish oil supplements (3\%), Sunnah supplements (2.2\%), and protein supplements (1.7\%). There have been significant genders differences for herbal supplements consumers as male $(10.1 \%)$ tend to consume it more as compared to female $(2.4 \%)$ with $p$-value 0.002 .

\section{Internal Factor: Level of Awareness}

It is found that majority of the respondents are aware of the benefits of their supplement standing at 51.2 percent (51.2\%). Together with the increase of the awareness of dietary supplement consumption, respondents are much aware of the importance, side effect, and objective of their consumption of dietary supplement. There are differences found in the awareness of respondents in reading the instruction attached with the supplement as female (51.3\%) tend to read it more as compared to male (43.5\%) with p-value 0.021 .

\section{Adverse Effect: Experience to Adverse Effect}

The respondents are reported Experience of Adverse Effect from dietary supplement consumption are reported in Table 4 below.

Table 5: Experience of Adverse Effect.

\begin{tabular}{lllll}
\hline & All (\%) & Male (\%) & Female (\%) & $\boldsymbol{p}$-Value \\
\hline Yes & 19.8 & 26.1 & 18.5 & 0.119 \\
\hline No & 80.2 & 73.9 & 81.5 & \\
\hline
\end{tabular}

There is higher percentage of respondents that have not experienced any adverse effects as compared to those who have experienced adverse effects; thus, there is no significance difference between student genders. 
INTERNATIONAL JOURNAL OF ACADEMIC RESEARCH IN BUSINESS AND SOCIAL SCIENCES

Vol. 11, No. 13, Beyond 2021 and COVID-19 - New Perspective in the Hospitality \& Tourism Industry. 2021, E-ISSN: 2222-6990 @ 2021 HRMARS

\section{Adverse Effect: Response}

Table 6: Response to adverse effect (\%)

\begin{tabular}{lllll}
\hline & All & Male & Female & $\boldsymbol{p}$-Value \\
\hline Did nothing & 4.2 & 10.1 & 14.1 & 0.007 \\
\hline $\begin{array}{l}\text { Stopped using dietary } \\
\text { supplement immediately }\end{array}$ & 12.4 & 8.7 & 13.1 & 0.308 \\
\hline Consult with family & & & & \\
\hline Complained to seller & 2.7 & 4.3 & 2.4 & 0.362 \\
\hline Went to the clinic or hospital & 0.2 & 0 & 0.3 & 0.650 \\
\hline
\end{tabular}

Most of the users that experienced adverse effect due to supplement consumption stopped consuming supplement (12.4\%), some did nothing (4.2\%), consulted with family $(2.7 \%)$, went to clinic $(2.0 \%)$, and complained to the seller $(0.2 \%)$. There is a big difference between genders for the symptom of nausea and vomiting with the female at 16.6 percent (16.6\%) who are majorly having these symptoms as compared to male at 10.1 percent $(10.1 \%)$ with $p$-value 0.029 .

\section{Conclusion}

A survey on the prevalence of dietary supplement intake among Bachelor Degree students from public universities in Terengganu has been conducted, and the results found that 30.9 percent (31\%) of the students are currently consuming dietary supplements. Furthermore, 26.7 percent (26.7\%) of the students previously used supplement, which adds up to percent in total 57.6 percent (57.7\%) known and consumed dietary supplement. In comparison to the percent of student that never used dietary supplement (42.3\%), they are still aware of the importance of dietary supplements. The consumption of the dietary supplement is due to several factors that related, which are classified into external factors, internal factors, and adverse effects. The most chosen sources to gain information regarding dietary supplement is through the internet $(37.9 \%)$ and bought it from the drugstore (40.2\%). The main reason for supplement consumption is to maintain health $(44.1 \%)$, and most of them are consuming vitamin supplement (37.2\%). Moreover, the level of awareness among students regarding dietary supplement is high (51.2\%). Inline to that, the number of supplement consumer among students that experienced adverse effects is low (19.8\%)

\section{Corresponding Author}

Fatimah Abd Ghani. Faculty of Hotel \& Tourism Management, Universiti Teknologi MARA, Dungun, Terengganu.

Email: fatim131@uitm.edu.my

\section{References}

Akabas, S. R., Vannice, G., Atwater, J. B., Cooperman, T., Cotter, R., \& Thomas, L. (2016). Quality Certification Programs for Dietary Supplements. Journal of the Academy of Nutrition and Dietetics. 
Alfawaz, H., Khan, N., Alfaifi, A., Shahrani, F. M., Al Tameem, H. M., Otaibi, S. F. A., \& Al-Daghri, N. M. (2017). Prevalence of dietary supplement use and associated factors among female college students in Saudi Arabia. BMC Women's Health.

Al-Naggar, R. A., \& Chen, R. (2011). Prevalence of Vitamin-mineral Supplements Use and Associated Factors Among Young Malaysians. Asian Pacific Journal of Cancer Prevention J Cancer Prev.

Axon, D. R., Vanova, J., Edel, C., \& Slack, M. (2017). Dietary supplement use, knowledge, and perceptions among student pharmacists. American Journal of Pharmaceutical Education.

Barnes, K., Ball, L., Desbrow, B., Alsharairi, N., \& Ahmed, F. (2016). Consumption and reasons for use of dietary supplements in an Australian university population. Nutrition.

Barrack, M., \& Gray, V. (2017). A Qualitative and Quantitative Evaluation of Dietary Supplement Topics Prioritized by Collegiate Athletes California State University, Long Beach in Partial Fulfilment of the Requirement.

Bessada, S. M. F., Alves, R. C., \& Oliveira, M. B. P. P. (2018). Caffeine-based food supplements and beverages: Trends of consumption for performance purposes and safety concerns. Food Research International.

Blumberg, J. B., Frei, B., Fulgoni, V. L., Weaver, C. M., \& Zeisel, S. H. (2017). Contribution of dietary supplements to nutritional adequacy in various adult age groups. Nutrients.

Chiba, T., Sato, Y., Kobayashi, E., Ide, K., Yamada, H., \& Umegaki, K. (2017). Behaviors of consumers, physicians and pharmacists in response to adverse events associated with dietary supplement use. Nutrition Journal.

Circella, G. (2017). What Affects Millennials' Mobility? PART II: The Impact of Residential Location, Individual Preferences and Lifestyles on Young Adults' Travel Behavior in California.

Fattahzadeh-ardalani, G., Farzaneh, E., Fathi, A., Molaei, B., \& Valizadeh, M. (2016). Determining the prevalence of dietary supplement consumption among Ardabil University students and related factors.

Jawadi, A. H., Addar, A. M., Alazzam, A. S., Alrabieah, F. O., Alsheikh, A. S. A., Amer, R. R., \& Badri, M. (2017). Prevalence of dietary supplements use among gymnasium users. Journal of Nutrition and Metabolism, 2017.

Knapik, J. J., Trone, D. W., Austin, K. G., Steelman, R. A., Farina, E. K., \& Lieberman, H. R. (2016). Prevalence, Adverse Events, and Factors Associated with Dietary Supplement and Nutritional Supplement Use by US Navy and Marine Corps Personnel. Journal of the Academy of Nutrition and Dietetics.

Kobayashi, E., Sato, Y., Umegaki, K., \& Chiba, T. (2017). The prevalence of dietary supplement use among college students: A nationwide survey in Japan. Nutrients.

Krejcie, R. V., \& Morgan, D. W. (1970). Determining Sample Size for Research Activities. Educational and Psychological Measurement.

Marx, W., Kiss, N., McKavanagh, D., \& Isenring, E. (2016). Attitudes, beliefs and behaviours of Australia dietitians regarding dietary supplements: A cross-sectional survey. Complementary Therapies in Clinical Practice.

Zaki, N. A. M., Rasidi, M. N., Awaluddin, S. M., Hiong, T. G., Ismail, H., \& Nor, N. S. M. (2018). Prevalence and Characteristics of Dietary Supplement Users in Malaysia: Data from the Malaysian Adult Nutrition Survey (MANS) 2014. Global Journal of Health Science. 
Naqvi, A. A., Ahmad, R., Abdul, A., Elewi, W., \& Alawa, A. H. (2018). Dietary supplement use among undergraduate male students in health and non-health cluster colleges of a public- sector university in Dammam, Saudi Arabia.

O’Brien, S. K., Malacova, E., Sherriff, J. L., \& Black, L. J. (2017). The prevalence and predictors of dietary supplement use in the Australian population. Nutrients.

Yeong, S. W., \& Choong, Y. C. (2017). Knowledge and characteristics of herbal supplement usage among community pharmacy customers in a Malaysian population. Complementary Therapies in Medicine.

Zezelj, S. P., Tomljanović, A., Jovanović, G. K., Krešić, G., Peloza, O. C., Dragaš-Zubalj, N., \& Prokurica, I. P. (2018). Prevalence, knowledge and attitudes concerning dietary supplements among a student population in Croatia. International Journal of Environmental Research and Public Health. 